\title{
Focus-Group Regarding the Psycho-Pedagogical Effects Felt by Children as a Result of the Parents' Migration
}

\section{Tiberiu Disca}

Assist. Prof.dr., 'Vasile Goldis` Western University of Arad

\begin{abstract}
The focus group method is a qualitative method which requires as technique the interview with a work group and a moderator. It is a research structure with scientific, social or public opinion commercial aim. In preparing the focus group I have determined the topic of the discussions based on an interviewing guide and I have determined the correspondence of the groups. Therefore, there had been five focusgroups, the discussions had a length of 75-90 min, recorded in an audio format, after receiving the subjects' permission. There were 5 focus-groups: focus-group 1: parents that have experienced first-hand migration but have returned back 7 men and 3 women); focus-group 2: parents/grandparents of the children with a migrant parent, enrolled at a Step-by-step or After school program ( 7 women and 4 men); focus-group 3: primary school teachers, school counsellors of the students with at least one migrant parent (9 primary school teachers, 2 counsellors); focus-group 4: parents/grandparents that have in their care at least one child after the migration of the parent(s) abroad (3 men, 7 women or 4 parents and 6 grandparents); focus-group 5: 10 school counsellors (psychologists) of the schools from the surroundings of Hunedoara (including Calan town and Pestis, Teliuc and Ghelari villages). In conclusions, the migration of a parent brings negative effects over the psychopedagogical evolution of the kid; all followed indicators have had negative effects after the migration, with the exception of the one that speaks about life conditions. Whether they have or not passed through an experience of migration, all subjects have affirmed that the absence of a parent or both has repercussions over the normal development of the child.
\end{abstract}

Keywords: focus-group, the migration, parent, children, school

\section{Introduction}

The focus group method is qualitative method which requires as technique the interview with a work group and a moderator. It is a research structure with scientific, social or public opinion commercial aim (Krueger \& Casey, 2000).

In our research, the focus group has at its base the following premises regarding the migration of a parent:

- determines a degradation of the familial environment

- induces an unfavourable educational climate 
- even if it improves the life conditions, it enhances the negative external influences

- it brings a deterioration of work style, of general behaviour and school, in particular

- contributes to a decrease of group participation

- generates impairment of attitude towards others and the self

In preparing the focus group I have determined the topic of the discussions based on an interviewing guide and I have determined the correspondence of the groups. Therefore, there had been five focus-groups, with the length of 75-90 min, recorded in an audio format, after receiving permission of the subjects.

There were 5 focus-groups:

- focus-group 1: parents that have experienced first-hand migration but have returned back ( 7 men and 3 women)

- focus-group 2: parents/grandparents of the children with a migrant parent and are enrolled at Step-by-step or After school program (7 women and 4 men)

- focus-group 3: primary school teachers, school counsellors of the students with at least one migrant parent (9 primary school teachers, 2 counsellors)

- focus-group 4: parents/grandparents that have in their care at least one child after the migration of the parent(s) abroad (3 men, 7 women or 4 parents and 6 grandparents)

- focus-group 5: 10 school counsellors (psychologists) of the schools from the surroundings of Hunedoara (including Călan town and Pestiș, Teliuc and Ghelari villages)

Regarding group 2, it must be mentioned that in Hunedoara town, at "Matei Corvin" Technical College and at "Iancu de Hunedoara" Informatics College there is one class per level for the educational alternative Step by Step, and at "Matei Corvin" Technical College there have been for a few years groups of children that attend the After school program. The participants of the 5 focus-groups organized were, therefore, 52 Romanian citizens, of which 38 women and 14 men.

The participation of the subjects at the interview was based on volunteering, without any financial reward or of any other nature, which we consider it will assure the cooperation in the focus-group of the (grand)parents interested about children and their scholarly grades, about their education and experiences, people who are in contact with the school, with the teachers from class.

The analysis of the research results:

\section{The familial environment and ties:}

This element has been processed mainly by highlighting the rapports established among the family (harmonious rapports, of understanding between parents and children; rapports marked by small and temporary conflicts; strong disagreement among the family, frequent and powerful conflicts; a family already or on its way to disintegration). Most subjects (46) have expressed their opinion, according to which a family where one of the parents is absent is not a normal family. The exception was 6 psychologists from group 5, which, based on scientific literature they are familiar with, have avoided the proposed terms (unwoven family, normal family, etc). 
Most have mentioned that these relationships were not affected negatively by the migration and they were about the same as before the migration.

"Their father wasn't interested in them even when he wasn't abroad, he was getting drunk and only then was he giving presents to the children"-the grandmother of student M.A.

"The departure of the father was a relief for the mother and the children, because there were always great quarrels, beatings especially at drunkenness" -the primary school teacher of student M.A.

3 subjects affirmed that the migration has contributed to the disintegration of the family or to its imminent disintegration. As concerning the relation between children and parent (migrants or not), most (39) affirm categorically that these relations have greatly worsened since the migration. Even if the migrants are in contact with the family, they usually talk to the remaining adults (the other parent or the grandparents) the recent problems and, even when talking to the children, they rarely (especially the father) have the patience and time to talk with the child. Migrants usually work overtime or lose a great part from their time communing from their workplace to their home (few Romanian workers live ear their workplace) which makes the hour children go to sleep be the same as the one when they return from work. The working conditions for emigrants are difficult, generating lots of stress and tiredness, which only worsens the relation parent-child. There are also cases of understanding and protectiveness coming from the other parent: "I told them many times not to tell Dad all problems, because he gets upset, we only bother him even more and that even so he can't solve them from there.." (A.V.'s mother)

\section{Conclusion}

The migration of a parent has contributed greatly to the aggravation of the familial environment. No person has affirmed that following the migration the environment became better, both in regards to the relation between spouses as well as the relation child-parent.

\section{The educational climate offered to the child}

All didactic personnel included in the study have affirmed that the families of the children with migrant parents offer an unfavourable educational environment to their scholarship (46 participants). Another 5 persons have stated that there is an adequate educational environment, and the father of B.Z. declared that for his children, the educational environment has become more favourable by the migration of the wife. "For a year and a half, since the wife has left to Ireland, we have enough money for everything the children need at school, there are no more problems. I take care of them at home, we make the homework together. I work as a night janitor to School $\mathrm{nr}$. 7, the wage is not big, but I am all day with them (he has 3 children of 15, 11 and 9 years old). The eldest is not so good at his studies, it was always like this, but the others are good. If the wife can stay one more year, two there we can clear all instalment and then we will see what we will do later..."

A part of the respondents (29) affirm however that this climate has not changed when the parents were home, but it was unfavourable even before the migration.

There are also 17 cases that recognize a worsening of the educational environment from the moment of departure. There are 8 cases where the homework is taken care of the older siblings and another 6 where the grandparents are more engaged in their education. 
Conclusion: All the educational personnel noted that the educational environment offered to the child has deteriorated. Even when there seems to be the same or has improved, the absence of a parent is nonetheless noticeable in the education of the child.

\section{Life and work conditions of the student}

No participant confirmed that the students have excellent conditions; there are 9 answers that speak about precarious conditions, 11 at the brink, 10 acceptable and 22 good. The cases where the parents have a longer migration experience are those that highlight an improvement of these conditions following the migration. There are also 3 cases where the mothers have left for at most a year and the fathers that remained home with the children state that since the departure of the mother the life conditions of the children are worse.

"When the husband left, we hoped that in 2-3 years we will solve all financial problems and then we will be a happy family, maybe make a new kid. After 4 years I realize we are still not done with all our debts, there is also the care towards the ill grandmother; the kids grow up without a father... We aren't alright!" (I.V.-mother)

'"We didn't become rich, we just managed to clear off some taxes to the bank, we still have more... The husband sends money home, but it isn't enough for me not to work too. Luckily with the mother who helps me with the little girl, otherwise... When I come tired from work I verify her homework, we discuss them on the telephone until then. But Roxana is a good girl, she usually makes her homework by herself and studies well." (mother of A.V.)

"The mother sends him money from Germany for all stupidities, he has all he needs at school, but nobody takes care of him more seriously. The father is neglectful, alcoholic, and E. is most of the time unsupervised."'(Primary school teacher)

Conclusion: All interviewed subjects recognize the improvement of students' life condition after the migration, but not of the work conditions for students and material sustaining necessary. Nobody agreed that the migration contributed to the assuring of some increased educational facilities (tutoring, extra-school activities that require financial sustaining, etc).

\section{Behaviour during the class}

According to the participants of the focus-group, the behaviour during class has become worse for 27 children. Primary school teachers and school counsellors, who know the best the students under the aspect of participating during lessons, consider that the departure of a parent can affect negatively the student's ability to focus on the topic of homework. The causes may be multiple, some deriving from the shortening the available time to supervise the child from the remaining parent who still has the same problems, others because of the emotional shock received by the child, generated by the absence of a parent, which manifests itself including by inattention. In such cases, the intervention of a school counsellor (psychologist) is opportune.

"Before, he was very attentive, he actively participated being always with the homework done, with the necessary instruments and because the parents were everyday at school, they brought him and took him from school. Since the father left, the mother comes at school only when called or at meetings and having another 2 younger children, she doesn't have too much time to take care of L.C. We have a notebook where to write everything, but sometimes the child forgets to 
write (especially at the classes I don't teach: English, religion, etc) and sometimes he mistakes the timetable, doesn't bring what he needs, etc" (P.L.-primary school teacher)

"At first, 2 years ago, in May, when his father left, and E.I. was 7 years old, I thought he had a time of inattention caused by the shock of the father's leaving, his playing partner. I even recommended the mother to take him to the psychologist, but he wasn't. The first year finishes and in the second one he continued with this attitude, which became more passive. He isn't too affected by bad grades, he isn't too happy about good ones, is more meditative and may times I 'lose him' during class: he doesn't know where to follow, he doesn't always write in time from the board, etc."(pr. sc. teacher N.M)

Conclusion: The fact that there are 9 cases where the behaviour during class hasn't modified shows that some teachers know how to recede the negative effects of migration. We consider the attitude of some teachers to place the whole responsibility on the parents for the behaviour of the students during lessons to be totally unproductive.

\section{Participation at group life}

Regarding the participation at group life, a number of 16 participants have mentioned the migration has generated a slight degree of self-isolation, 21 affirm that, generally, there were no chances in the behaviour of the children, those who were withdrawn before, remained withdrawn, while those who were sociable have maintained this attitude.

"I cannot say she has changed her attitude towards friends, towards others. She is more emotive by her nature, until she gets used with the people, otherwise she is relaxed. From time to time she is daydreaming, she told me a few times she was thinking about dad, but beside that she is the same" (mother of I.V.)

The discussion continued however on the edge of the evolution of the role the child has in groups. This way, after the migration and the fact that the financial status has improved, some kids (12) have modified their position in group, meaning they became the most important in their group, being suppliers of financial resources or toys (balls, bats, guns, dolls, etc); 5 mothers have affirmed that, against this, their children became 'prissier', are more irascible, they get more easily upset among the group and have bigger pretensions at different objects, comparing themselves to their group friends.

"Not long ago, they started to look for him. Before they weren't really coming after him, but now, since he has guns bought by his father from Germany, all kids from the neighbourhood are waiting for him to come and play outside." (R.O.'s mother)

Conclusions: As an effect of the migration, the children have cut off contact with some persons whom they interrelated during the participation at cultural-sportive circles, but they have gained a somehow superior rank among their friends circles or among the family, acquaintances.

\section{Attitude towards others}

At this topic, most participants (28) affirmed, at the beginning that, if there is a change, is related rather to the age than to the migration of the parents. However, after diving further into the issue, the debates have shown that the migration of a parent has created some particular manifestations and attitudes different from the other children. The absence of a 
parent is usually filled in by older siblings or other relatives (generally grandparents). Therefore, a part of paternal/maternal feelings tend to be assigned to these persons, sometimes even in their language, so that the grandmothers sometimes called 'mother' and the grandfather 'father'. 2 teachers have stated that, especially girls are more attached to them when the mother is abroad. There are cases where there was established a 'ritual' among the family to mention the parents during their physical absence. There are also reverse effects, in the direction of isolation towards the others and even manifesting a few minor phobias, particularly girls, towards adults of the opposite gender.

"When we all sit together to eat, there is always an empty chair for 'father' and the children know that the father is part of the family, even if he is physically absent and they see him only on Internet. When guests are coming, usually there is nobody sitting on that chair and if it is offered to somebody, they get told that is 'dad's chair'. Then, when he comes home, they all see to it that he regains his established place" (mother of G.A)

"We have whole rituals of 'good night' with photos and dolls to remember of the mother. The photo is kissed, the dolls are hugged. She sleeps with dolls dressed in mother's clothes." (C.V.'s father)

"A few times, M.A. came and hugged me and told me 'You are my mother!'. The first time it shocked me, I didn't say anything, but the third time I told her she has a mother that can't wait to see her, that she suffers a lot her mother for her future, that after the $4^{\text {th }}$ grade I will be only a memory for her, but that her mother will always remain her mother all her life. Even so, she has a few moments of tenderness with me she didn't have while the mother was in country."(Teacher P.R.)

\section{Conclusions: The absence of the father or mother creates, in the first place, an empty 'place' in the family, place the child tends to fill with close acquaintances. "If these moments of tenderness the child has with others were to be recorded video, the parents would return home, out of jealousy, urgently." (Counsellor F.A.)}

\section{Attitudes towards the self}

The absence of a parent is felt by the children mainly by the sentiment that he is no longer given the necessary attention. Being an only child or he has siblings, either way for a child love means in the first place care.

The migration of the parents determines, by their absence, their kid to feel neglected. These feelings were confirmed by all the participants of the focus-group. 24 persons confirmed that this type of thoughts and feelings have affected the children the moment they received the information that their parent will leave for a longer time. With time, these emotions become blurry. The kids come to learn they weren't neglected, the migrants contributing to the change of these opinions and attitudes by multiple means: discussions, constantly reiterated declaration with words that send the message of 'love towards the kid' in daily conversations, presents for different birthdays, rewards for good grades, etc. Even so, 18 persons declare that even now there are children that say they are neglected, that they are not important enough for the migrant parents. In fact, starting from the sentimental state where they feel cast aside, children end up diminishing their self-esteem.

"Many times I told my wife not to scold the kids when she talks with them on Internet, not to reproach them some failures, mistakes, etc so as not to increase their distrust in their own 
capabilities. For months we had to fight to convince C. that mom left because she loves us and doesn't want us to become worse."(father, F.R.)

"Dad left because I didn't behave well and he was ashamed to go outside with me in park'. This phrase he told me many times, $V$. being sure he didn't deserve being close to his father. It is painful to hear such words from a 6 year old boy and to prove him the contrary." (F.V.'s mother)

Another aspect brought in discussion, initially unforeseen, but that was frequently repeated is the labelling realized by the other kids. Usually, children with parents abroad are welcomed in groups of equals, for they can supply material resources (money, toys) that the groups didn't have in the first place. However, especially during conflicts and upsets, the children with migrant children are the most exposed to insults, reproaches, mockeries from the other kids.

Some of the insulting words preferred by children regarding the absent parents are either invented by themselves, either taken from other children or adults, or even from mass-media (especially from TV): "beggars (31), strawberriers (25), thieves (23), traitors (18), unRomanians (16), mother or father with no soul (15), bitches and leeches (13), gypsies (11), divorced (10), swan-eaters (5), refugees (5), carters (2), bozgors/ no country's man (1)"

At the same time, the kids are named too: "left behind (37), without mother or father (36), abandoned (34), orphans (28), isolated (5), scoundrels (3)"

Conclusions: The parent that left cannot give the child the same self-trust he had while he was in country. The insults or reproaches of the others manifest themselves also regarding the migration, which brings a certain degree of vulnerability.

\section{General conclusions gathered after applying the focus-group method}

After the focus-groups that took place in research, there are several relevant conclusions:

- The migration of a parent brings negative effects over the psycho-pedagogical evolution of the kid; all followed indicators have had negative effects after the migration, with the exception of the one that speaks about life conditions.

- Whether they have or not passed through an experience of migration, all subjects have affirmed that the absence of a parent or both has repercussions over the normal development of the child.

- With small differences, most of the indicators have had the same perception among the participants of the focus-group (whether parents, grandparents, teachers). There is unanimity of opinions that the family where one parent is not home cannot be considered normal, no matter what everyone understands by normality.

- Surprisingly, the migration of parents brings a diminishing of frequenting artistic and sportive groups, especially among girls.

- The absence of a parent is felt by the child mainly by the fact that (s)he is no longer accorded the necessary attention. Very important is that what have had affirmed 24 persons: that these thoughts and feelings have fainted by different gestures made by the migrant: discussions, constantly reiterated declaration with words that send the message of 'love towards the kid' in daily conversations, presents for different birthdays, rewards for good grades, etc. What is even worse is that from the point where they feel neglected the children reach the point where they lack self-esteem, believing that actually they are 
the reason their parents do not pay enough attention to them. At these there are also added traumas created by classmates and playmates, especially at quarrels and upsets, when they are addressed multiple insults, reproaches, mockeries from other kids.

\section{Discussion}

The use of the focus-group method allowed the building of a social environment which stimulated the answers. The social interactions between the interviewed individuals led to new ideas, towards a sincerity which was not present in an individual interview. The diversity of individual experiences were, for some, for the first time integrated in a social environment. The dynamics of the groups allowed the building of answers for the topic, which determined the disappearance of some subjects' reticence, who were less willing to collaborate. The focus group favored the under standing of the mechanism which cause, uphold or annihilate particular attitudes and the information has a high level of fidelity and validity.

I have tried to nullify the group effects that take place either because of the group's increased cohesion, either because the members of group are well-acquainted. Therefore, there were no other groups formed on other occasions, but they were for the first time integrated in such a social context.

The limits are determined by the fact that the results may have a relative validity compared to the general population. The information, data and elements obtained after the focus group have an empiric trait, in other words, they are presented in a form as unaltered al possible, without being managed or influenced by the moderator.

Hence, a research of this kind must be associated with other qualitative methods (like case studies) but also with quantitative ones (quiz, questionnaire).

\section{References}

[1] Baldassar L., Merla L., (2013), Transnational Families, Migration and the Circulation of Care, Understanding Mobility and Absence in Family Life, Routlege;

[2] Bălţătescu S., Bacter C. (2016), Bunăstarea văzută prin ochii copiilor români: rezultatele studiului internaţional „Lumea copiilor” (ISCWeB), Presa Universitară Clujeană;

[3] Chipea F., Bălțătescu S., (2010), Copiii lăsaţi acasă de emigranţi. Studiu în judeţul Bihor, Sociologie Românească, vol. VIII nr. 4

[4] Chipea, F. (2001), Familia contemporană - tendinţe globale şi configuraţii locale, Editura Expert, Bucureşti;

[5] Krueger R.A. \& Casey M.A. (2000), Focus Groups. A Practical Guide for Applied Research (3rd Edition). Thousand Oaks, CA: Sage Publication

[6] Mihăilescu I., (2003), Sociologie generală : concepte fundamentale şi studii de caz , editura Polirom, Iaşi ;

[7] Onuţ Gh. (2014), Cercetarea sociologică, Editura Trinitas, București;

[8] Sandu D., (2010), Lumile sociale ale migrației româneşti în străinătate, Editura Polirom, Iaşi; 
[9] Sîrca V., (2014), Migraţia românească postdecembristă: focus grup cu specialişti, Anuarul Institutului de Istorie "George Baritiu" din Cluj-Napoca, vol. XII, 2014. 